\title{
De rolstoel als meetinstrument
}

Citation for published version (APA):

Troost, J. (1993). De rolstoel als meetinstrument. Maastricht University. https://doi.org/10.26481/spe.19930129jt

Document status and date:

Published: 29/01/1993

DOI:

10.26481/spe.19930129jt

Document Version:

Publisher's PDF, also known as Version of record

\section{Please check the document version of this publication:}

- A submitted manuscript is the version of the article upon submission and before peer-review. There can be important differences between the submitted version and the official published version of record.

People interested in the research are advised to contact the author for the final version of the publication, or visit the DOI to the publisher's website.

- The final author version and the galley proof are versions of the publication after peer review.

- The final published version features the final layout of the paper including the volume, issue and page numbers.

Link to publication

\footnotetext{
General rights rights.

- You may freely distribute the URL identifying the publication in the public portal. please follow below link for the End User Agreement:

www.umlib.nl/taverne-license

Take down policy

If you believe that this document breaches copyright please contact us at:

repository@maastrichtuniversity.nl

providing details and we will investigate your claim.
}

Copyright and moral rights for the publications made accessible in the public portal are retained by the authors and/or other copyright owners and it is a condition of accessing publications that users recognise and abide by the legal requirements associated with these

- Users may download and print one copy of any publication from the public portal for the purpose of private study or research.

- You may not further distribute the material or use it for any profit-making activity or commercial gain

If the publication is distributed under the terms of Article $25 \mathrm{fa}$ of the Dutch Copyright Act, indicated by the "Taverne" license above, 


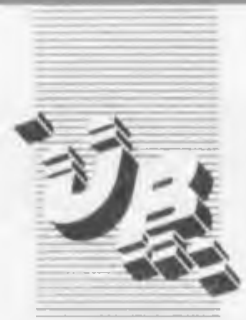

De uitleentermijn verstrijkt op
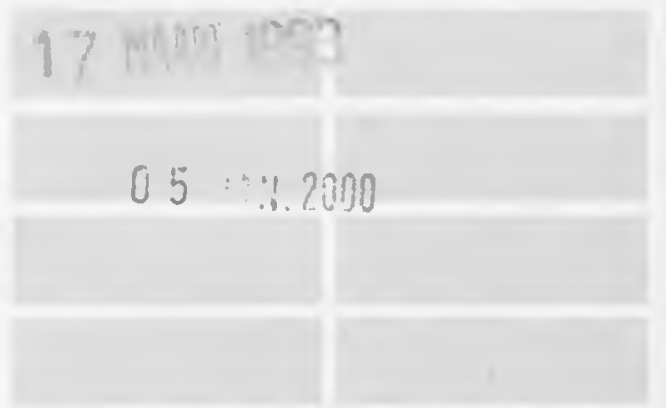

Rıjksuniversıleıl Lımburg Postbus 616 6200 MD Maastrichı

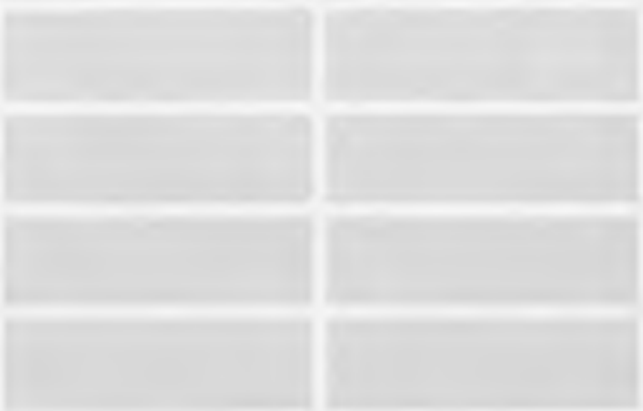

Gelıeve deze publıcatie tijig te retourneren of (telefonisch) verlenging van de uitleentermijn aan te vragen.

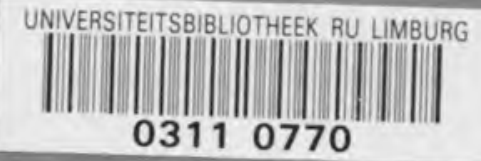




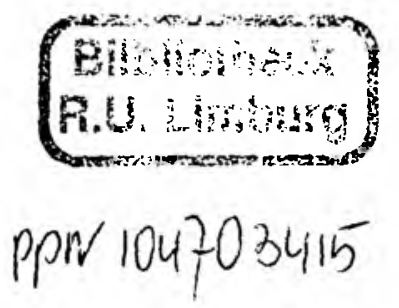


Mijnheer de Rector Magnificus

Leden van de Universitaire Gemeenschap

Zeer geachte Toehoorders

Klinische Neurologie geldt als een vak met weinig therapeutische mogelijkheden. Wat is de reden dat zovelen overtuigd zijn van het feit dat de Neurologie therapeutisch weinig te bieden heeft? Er zijn immers in de Geneeskunde op vrijwel elk gebied ziektebeelden, die met de huidige kennis niet of slechts symptomatisch te behandelen zijn.

Een belangrijke reden voor deze opvatting wordt veroorzaakt door het feit dat neurologische aandoeningen vaak aanleiding geven tot in het oog vallende functiestoornissen. Indien iemand een hartinfarct beeft doorstaan en hiervan goed is hersteld, is aan de buitenkant het litteken in de hartspier niet zichtbaar en kan slechts met aanvullend technisch onderzoek worden aangetoond. De patiënt daarentegen die geen hartinfarct, maar een herseninfarct, een beroerte, goed heeft doorstaan, toont meestal nog zichtbare stoornissen, waarvan ook de leek kan zien dat iets niet normaal functioneert. Dit verschil, n.l. het feit of je bij directe observatie een stoornis kunt zien of niet is naar mijn mening een van de belangrijkste redenen voor de pessimistische opvattingen over de therapeutische mogelijkheden in de Neurologie.

Tevens zijn deze handicaps een van de problemen in de evaluatie van een behandeling. Het al of niet vaststellen van een handicap is in het algemeen niet al te moeilijk. Vaststellen of een handicap iets is toe- of afgenomen is vaak buitengewoon lastig. Er bestaan hiervoor dan ook vele min of meer bruikbare invaliditeitsschalen, vaak verschillend voor de diverse neurologische aandoeningen. Zeker bij die neurologische aandoeningen die door de aard van de kwaal al een sterk wisselend beloop hebben, bijv. multipele sclerose, wordt het soms bijna ondoenlijk om de effekten van een behandeling betrouwbaar te meten. Een onderzoeker naar de effekten van bepaalde behandelingen bij M.S. slaakte daarom eens de verzuchting, dat de enige goed te meten maat het verschil in het aantal rolstoelen voor en na de behandeling is.

Toch zijn deze pessimistische opvattingen onjuist. De therapie in de Neurologie heeft zich de laatste decennia spectaculair ontwikkeld. Toen ik in 1965 mijn opleiding in de 
Neurologie begon, verscheen in datzelfde jaar van de hand van Van Crevel een therapeutisch vademecum. De vooruitgang in de behandelingsmogelijkheden blijkt pas goed als we de huidige gebruikelijke behandelingen vergelijken met die van 1965.

Zonder nu de tijd te vullen met een farmacotherapeutisch overzicht van de Neurologie, wil ik U enkele ontwikkelingen schetsen. Tevens zal ik, zeer voorzichtig, enkele toekomstverwachtingen aangeven. Voorzichtig, teneinde niet te vervallen in door Canetti beschreven stilte: "Er sucht von der Zukunft zu sprechen, fühlt sich als Stümper und verstummt."

Ik zal mij concentreren op de vooruitgang in de behandeling van enkele typische neurologische ziektebeelden. Aandoeningen, tengevolge van vaatziekten, kwaadaardige nieuwvormingen en infectieziekten volgen in hun behandelingsmodaliteiten de ontwikkelingen zoals die ook in andere gebieden binnen de Geneeskunde plaatsvindt. Op al deze terreinen wordt meer of minder vooruitgang geboekt. Zo zijn er thans mogelijkheden bij een dreigende beroerte om erger te voorkomen. De behandeling van een patiënt die een beroerte heeft, is nog aanmerkelijk minder succesvol. De aanvankelijk grote successen in de behandeling van infectieziekten van het zenuwstelsel worden de laatste jaren overschaduwd door de toename van het aantal resistente bacteriestammen en door ziekten die gepaard gaan met AIDS.

\section{DEGENERATIEVE ZIEKTEN}

Wat wordt er in de Neurologie verstaan onder degeneratieve ziektebeelden.

"Degeneratief" betekent in dit verband, dat er geen vasculaire ziekte is, geen infectie, geen tumor en geen histologische clou voor de oorzaak. De cellen verliezen hun vitaliteit, verschrompelen en verdwijnen. Meestal betreft het een speciaal type zenuwcel, die voor de diverse ziektebeelden verschilt. De ziekten zijn zonder uitzondering progressief van aard en komen soms binnen dezelfde familie voor en, maar zelden, binnen én individu. Voor deze ziektebeelden zijn er talloze theorieën aangaande hun ontstaanswijze en daardoor zijn er ook talrijke onderzoeksstromingen. Zo wordt er bijv. gezocht naar toxische invloeden vanuit het milieu en naar genetische oorzaken.

Tot de groep van degeneratieve neurologische aandoeningen behoren o.m. de ziekte 
van Parkinson en andere bewegingsstoornissen, de ziekte van Alzheimer en de Amyotrofische Lateraal Sclerose. De vooruitgang van de behandelingsmogelijkheden is het meest spectaculair bij de ziekte van Parkinson.

\section{DE ZIEKTE VAN PARKINSON}

De ziekte van Parkinson is een tamelijk frequent voorkomende aandoening met een geschatte incidentie van 20 nieuwe patiënten per 100.000 inwoners per jaar. De geschatte prevalentie, dat is het totale aantal patiënten op een gegeven tijdstip, bedraagt 150 per 100.000 inwoners. Zowel incidentie als prevalentie nemen toe met de leeftijd. Het is de enig bekende ziekte die minder vaak bij rokers voorkomt.

De ziekte begint meestal op de leeftijd van 50-70 jaar en verergert langzaam in de loop van enkele jaren, tot de patiënten tenslotte geheel bedlegerig zijn en overlijden aan longontsteking, urineweginfecties of sepsis. De eerste verschijnselen zijn o.m. vermoeidheid, een zekere rusteloosheid en enkel- of dubbelzijdige gevoelsveranderingen zoals koude gevoelens, brandende sensaties, doofheid en tintelingen. Deze symptomen kunnen blijven bestaan of gaan tenslotte op in de hoofdsymptomen van de ziekte, te weten tremoren, stijfheid en bewegingsarmoede. De verschijnselen beginnen meestal in een ledemaat of een lichaamshelft en het kan soms jaren duren voordat ook de andere lichaamshelft is aangedaan. Tot in zeer late stadia van de ziekte blijft er een asymmetrie bestaan van de motorische stoornissen. Bijkomende symptomen zijn o.a.

- gewricht- en spierpijn

- excessieve talgafscheiding

- kwijlen als gevolg van het onvoldoende doorslikken van speeksel

- depressiviteit.

De ziekte wordt veroorzaakt door het selectieve teloorgaan van bepaalde zenuwcellen in de hersenstam, het verdwijnen van bepaalde zenuwbanen en de vorming van speciale insluitlichaampjes in zenuwcellen, de zg. Lewy bodies. Als gevolg van het verdwijnen van deze zenuwcellen ontstaat er een tekort aan dopamine, een stof die belangrijk is voor de prikkeloverdracht tussen bepaalde zenuwcellen in de hersenen. Een dergelijke stof wordt een neurotransmitter genoemd. Het gevolg van een tekort 
aan deze neurotransmitter is dat andere delen van de hersenen onvoldoende gestimuleerd worden met als uiteindelijk gevolg de reeds genoemde klinische verschijnselen, die zich pas voordoen wanneer meer dan $70 \%$ van de betroffen zenuwcellen verdwenen zijn.

Waaruit bestaat nu de therapeutische winst in de behandeling van de ziekte van Parkinson?

Het belang van de neurotransmitter dopamine voor het ontstaan van de klinische symptomen werd duidelijk in het begin van de zestiger jaren. In die periode werden ook de eerste pogingen gedaan met het toedienen van een chemische voorloper van dopamine, het L-Dopa, aan parkinsonpatiënten; eerst nog middels een directe intraveneuze toediening doch al snel door de orale toediening van de stof L-Dopa. Het middel bleek de symptomen van de ziekte beter te bestrijden dan alle tot dan gebruikte middelen. Toch werd al spoedig duidelijk dat er ook bezwaren kleefden aan het gebruik. Allereerst veroorzaakte het bij veel patiënten klachten over misselijkheid en overgeven, doch mogelijk nog storender was het optreden van bewegingsstoornissen na langdurig gebruik van het middel. Het eerstgenoemde bezwaar kon grotendeels voorkomen worden door het toevoegen van een stof die de werking van het $\mathrm{L}$ Dopa buiten het zenuwstelsel blokkeert. Daarnaast werd L-Dopa gecombineerd met een stof die de afbraak in het lichaam buiten het centrale zenuwstelsel voorkomt, een zg. decarboxylase-remmer. Als gevolg van de combinatie van L-Dopa met een dergelijke decarboxylase-remmer was de voor de bestrijding van de symptomen benodigde hoeveelheid L-Dopa geringer, met als gevolg minder bijwerkingen. Toch bleven de genoemde bewegingsstoornissen, in de zin van een overmatige beweeglijkheid of krampende bewegingspatronen, niet uit.

In het midden van de jaren ' 70 werden stoffen ontdekt die de receptoren van het dopamine gevoeliger maakten voor stimulatie hiermee. Een combinatie van een dergelijke receptor-agonist met L-Dopa + decarboxylase-remmer veroorzaakte een verdere daling in de dagelijks benodigde hoeveelheid L-Dopa.

Over de vraag met welk middel en in welke doseringen nu begonnen moet worden, bestaat tussen parkinsondeskundigen een wisselend verschil van inzicht. De behandeling bestaat nu dus uit een toevoeging van de ontbrekende neurotransmitter en een gevoeliger maken van de receptor voor deze stof. Een derde benaderingsweg bestaat 
uit het vertragen van de afbraak van de dopamine, zodat deze zijn werking langer kan uitoefenen. Deze benadering werd mogelijk in het eind van de jaren '70 door de ontwikkeling van een stof die een van de enzymen, die verantwoordelijk zijn voor de afbraak van dopamine, in zijn activiteit afremt, een zg. mono-amine oxydase-remmer. Deze MAO-remmer, deprenyl, werd voor het eerst in 1976 door Birkmayer in Oostenrijk toegepast. Het gebruik van dit middel leidde tot een heftige, tot nu toe nog niet afgesloten, wetenschappelijke discussie. Birkmayer beweert nl. dat deprenyl niet alleen een gunstig effekt heeft op de symptomen van de ziekte van Parkinson, en daardoor dopa-sparend is, maar dat het ook de progressie, dus de verergering, van de ziekte afremt. De stof zou neuro-protectieve eigenschappen hebben, iets wat alle andere tot dusver bekende middelen met zekerheid niet hebben. Deze discussie spitste zich toe na de ontdekking van het specifiek neurotoxische effekt van MPTP. MPTP (1-methyl-4 phenyl-1,2,3,6 tetrahydropyridine) is een in 1947 gesynthetiseerde stof, die aanvankelijk zelfs als een anti-parkinsonmiddel is getest. De stof werd toxicologisch belangrijk toen in het begin van de jaren '80 een andere stof MPPP (1methyl-4 proprionoxypiperidine) in kleine laboratoria werd vervaardigd als een illegaal narcoticum. De synthese van MPPP in clandestiene laboratoria leidt echter altijd tot verontreiniging met MPTP. In 1982 veroorzaakte dit in Californië bij groepen jonge druggebruikers vergevorderde stadia van een parkinsonsyndroom door een intoxicatie met MPTP. De door deze intoxicatie veroorzaakte parkinsonsymptomatologie is identiek aan de ziekte van Parkinson, afgezien van dementiële symptomen.

De "epidemie" had 3 belangrijke gevolgen. Allereerst bleek het met deze stof mogelijk bij proefdieren en m.n. primaten, klassieke parkinsonsymptomen op te wekken. Voor het eerst was er nu dus een goed diermodel beschikbaar voor de verdere bestudering van de parkinsonsymptomen. In de tweede plaats werd de mogelijkheid dat de ziekte van Parkinson het gevolg is van een toxische stof, die zich in het milieu bevindt, weer actueel. De stof MPTP bleek nl. niet alleen via een directe intraveneuze weg opgenomen te worden, maar ook via huidcontact en inhalatie van MPTP bevattende dampen. Dit betekent dat er stoffen bestaan die selectief neurotoxisch zijn, een parkinsonsyndroom kunnen veroorzaken en ook ongewild in het lichaam kunnen komen. 
Tenslotte bleek bij dierexperimenteel onderzoek dat indien de proefdieren alvorens met MPTP te worden belast, werden voorbehandeld met een MAO-B-remmer, nl. deprenyl, de dieren beschermd waren tegen het optreden van een parkinsonsyndroom. Is er dus toch neuroprotectie mogelijk?

Deze en andere bevindingen leidden er toe dat in de Verenigde Staten een groot opgezette trial wordt uitgevoerd, de zg. Datatop trial met o.m. als vraag of deprenyl neuroprotectie biedt. Een eerste tussentijdse analyse gaf een mogelijk positief antwoord op deze vraag. De discussie is echter nog niet beëindigd en andere onderzoekers zijn nog van mening, dat het effekt uitsluitend symptomatisch is.

Samenvattend zijn de farmacotherapeutisch mogelijkheden voor de behandeling van de ziekte van Parkinson nu:

1. toevoeging van L-Dopa + decarboxylase-remmer,

2. al dan niet in combinatie met een receptor-agonist

3. tezamen met een MAO-B-remmer die mogelijk ook neuroprotectie biedt.

Als bijkomende, doch duidelijk minder belangrijke medicamenteuze behandeling beschikt de behandelend neuroloog nog over anticholinergica en amantadine. Met behulp van deze middelen lukt het veelal de patiënten gedurende meerdere jaren in een goede algemene toestand te houden, waarbij de mobiliteit goed tot acceptabel is en ook de overige functies bevredigend blijven. Onvermijdelijk komt echter het moment dat de bijwerkingen van de Dopatherapie hinderlijk worden of het effekt van het middel duidelijk afneemt doordat de ziekte verder is voortgeschreden. Door toedieningspatronen van de medicatie te variëren lukt het dan nog om enige tijd respijt te krijgen. Ook zijn sommige bijwerkingen toegankelijk voor medicamenteuze therapie.

\section{Toekomstige ontwikkelingen}

Zijn er nu op afzienbare termijn andere behandelingsstrategieën denkbaar die het ziekteproces in gunstige zin beïnvloeden.

Sedert 5 jaar is er grote belangstelling voor de mogelijk gunstige effekten van weefseltransplantaties in de hersens van parkinsonpatiënten. Successen zijn gemeld van de transplantatie van autoloog bijniermergweefsel en van foetaal mesencephaal 
(dopaminerg) weefsel. Claims over succesvolle bijniermergtransplantaties leiden tot frequente navolging waarbij de aanvankelijk beschreven successen niet bevestigd werden. Deze methode is nu dan ook weer verlaten. Een voorzichtig optimisme betreffende toekomstig succes met behulp van implantatie van foetaal weefsel is echter nog aanwezig. Deze methode bleek ook succesvol bij de behandeling van proefdieren met een parkinsonsyndroom t.g.v. MPTP. Zeer onlangs, december 1992, werden gunstige effekten bij mensen beschreven bij wie foetaal mesencephaal weefsel was geïmplanteerd. In twee van de drie studies ging het om parkinsonpatiënten met al een ver voortgeschreden vorm van de ziekte die al langere tijd met medicamenten waren behandeld. In de derde studie betrof het twee jonge volwassenen met een ernstig door MPTP geïnduceerd ziektebeeld. De verbetering was met name bij de laatste categorie opmerkelijk.

De gebruikte implantatietechnieken varieerden hetgeen eveneens van invloed op de resultaten kan zijn. En hoewel volgens voornoemd artikel cynici zouden kunnen beweren dat de verbetering het effekt is van het door de implantatie aangebrachte letsel in de hersenen, trad de verbetering niet op bij de implantatie van bijniermergweefsel waarbij ongeveer identieke letsels worden gemaakt. Naar alle waarschijnlijkheid is het dus het dopaminerge weefsel dat aanleiding geeft tot de verbetering. Hoe lang deze verbetering aanhoudt en of de geïmplanteerde dopamine producerende cellen onderhevig zullen zijn aan hetzelfde degeneratieve proces als de oorspronkelijke cellen is onzeker. Hoewel de procedure niet verstoken lijkt van een zeker therapeutisch succes, belanden we wel onmiddellijk in ethische en zelfs politieke problemen. De vraag centreert zich rond het probleem of er, en zo ja, in hoeverre research mag worden verricht met menselijk foetaal weefsel dat door abortus wordt verkregen. Een hiervan afgeleid probleem is, of onderzoek naar transplantatie van foetaal weefsel een toename zou kunnen veroorzaken van het aantal abortussen.

In de Verenigde Staten werden deze en aanverwante ethische problemen nader beschouwd door "the Human Fetal Tissue Transplantation Research Panel" bestaande uit 21 experts van diverse disciplines waaronder medici, juristen en ethici. Ook waren in deze commissie tegenstanders van abortus vertegenwoordigd. Een grote meerderheid van deze groep, 18 voor en 3 tegen, vond de research toelaatbaar en vond dat het ook in aanmerking kwam voor regeringssubsidies. Deze aanbevelingen werden 
overgenomen en wel unaniem door een adviescollege van de National Institutes of Health. Desondanks handhaafde de regering Bush het door de regering Reagan ingenomen standpunt dat dit type onderzoek niet voor financiële steun uit de algemene middelen in aanmerking komt.

Zoals $U$ ziet, bestaan er dus grote ethische en ook politieke problemen ten aanzien van de verdere ontwikkeling van deze mogelijke behandelingswijze.

\section{Vrije radicalen hypothese}

Het MPTP model heeft nog op andere wijze invloed gehad op ons denken betreffende de ziekte van Parkinson. Hoewel zo langzamerhand duidelijk is dat de verschijnselen van de ziekte van Parkinson een gevolg zijn van een tekort aan de neurotransmitter dopamine als gevolg van het verdwijnen van specifieke zenuwcellen in een omschreven zenuwkern in de hersenstam, de zg. substantia nigra, is de reden voor dit celverlies nog onbekend. Een recente hypothese voor dit celverlies is de beschadiging van deze cellen door vrije radicalen. Dit zijn chemische stoffen die een niet gepaard of vrij electron bevatten en daardoor chemisch zeer gemakkelijk reacties aangaan. Het betreft hier vnl. oxyradicalen, d.w.z. vrije radicalen waar het viije electron gelokaliseerd is aan een zuurstofatoom, het superoxide anion radicaal. Deze stoffen zijn toxisch voor de cel en leiden tot een versnelde afbraak van cellen.

Een argument dat dit concept steunt, is de aanwezigheid van hoge concentraties ijzer in de substantia nigra dat de oxidatieve vorming van vrije radicalen katalyseert. Ook deze hypothese steunt dus de aanname van de beschermende werking van MAO-Bremmers op de progressie van de ziekte.

Een ander argument voor de hypothese volgt uit bepaalde dierexperimenten, waarbij 6-hydroxydopamine (6-OHDA) lokaal in de substantia nigra worden geïnjiceerd. 6OHDA reageert met moleculair $\mathrm{O}_{2}$ en vormt superoxide-anion radicalen, waterstofperoxyde en hydroxyl radicalen. De specificiteit van 6-OHDA hangt af van de selectieve opname en ophoping in catecholamine neuronen en zenuweindigingen. Hierdoor worden selectief de nigro-striatale dopaminerge banen beschadigd. Bij ratten en muizen ontstaat dan een parkinsonachtig beeld. Stoffen die bovengenoemde radicalen wegvangen, $\mathrm{zg}$. scavengers, beschermen muizen tegen het ontstaan van deze verschijnselen. 
Dit laatste is dan, op theoretische gronden, een reden om mensen met parkinsonsymptomen radicalen scavengers toe te dienen in de verwachting dat daardoor de symptomen of het beloop veranderen. Zulke scavengers zijn bijv. vit. $\mathrm{C}$ en vit. $\mathrm{E}$. Tekorten van deze stoffen veroorzaken zeer uiteenlopende aandoeningen waar echter nooit parkinsonsymptomen toe behoren.

Hoewel uit het voorgaande duidelijk moge zijn dat er grote vorderingen zijn geboekt in de behandeling van de patiënt met ziekte van Parkinson, behoort genezing nog niet tot de mogelijkheden en veroorzaken de thans beschikbare effektieve symptomatische behandelingsmethoden op de lange duur bijwerkingen. Er is dus hier ook nog veel onderzoek, met name ook klinisch onderzoek in de vorm van trials nodig. De verdere resultaten van de nog lopende Datatop Trial met de centrale vraag naar de beschermende werking van $\mathrm{MAO}-\mathrm{B}-\mathrm{remmers}$ worden dan ook met spanning tegemoet gezien.

Andere therapeutische mogelijkheden worden nog onderzocht, bijv. de synthese van nieuwe receptor-agonisten en remming van het dopamine metabolisme. Dopamine wordt met behulp van twee enzymen in het lichaam afgebroken, nl. het al besproken MAO-B en verder door het cathechol-O-methyltransferase, afgekort COMT. Selectieve remmers hiervan worden thans ontwikkeld.

Tenslotte zijn er aanwijzingen dat een overmatige activiteit van een andere hersenkern, de nucleus subthalamicus, bijdraagt aan de parkinsonsymptomen. Dit blijkt o.m. uit het feit dat bij apen met parkinsonsymptomen t.g.v. MPTP, verbetering optrad door chirurgische letsels te maken in deze kern. Deze kern maakt gebruik van de transmitter glutamaat die middels een bepaalde glutamaatreceptor zijn werking ontplooit. Blokkade van deze receptor subtype vermindert ook bij proefdieren de parkinsonverschijnselen.

\section{MIGRAINE}

Een neurologische aandoening die op het eerste gezicht minder spectaculair is dan de ziekte van Parkinson is migraineuze hoofdpijn. Gezien echter het frequente voorkomen en de sociaal-economische gevolgen van migraine aanvallen is deze aandoening 
in het totaal van de volksgezondheid bezien van groot belang. Ook hier zijn de laatste jaren successen geboekt die eveneens, althans in Nederland, hebben geleid tot politiek ingrijpen gezien de kosten van de nieuwe medicamenten.

Waar gaat het om?

Teneinde deze vraag enigermate te kunnen beantwoorden, is het nodig iets te zeggen over de huidige opvattingen over de oorzaak van migraineuze hoofdpijn.

Wat is migraine?

Ieder van $U$ kent mensen die al dan niet frequent lijden aan migraine aanvallen. In de belletrie worden regelmatig lijders aan migraine beschreven en vaak betreft het dan karakterologisch bezien een speciaal type mensen, dat evenwel niet overeenkomt met de neurologische praktijk.

Migraine is een episodische stoornis die gekarakteriseerd wordt door hoofdpijn gepaard gaande met misselijkheid, braken, overgevoeligheid voor licht en geluid. Een internationale Headache Society heeft een bepaald classificatiesysteem voor hoofdpijnen ontwikkeld en beschrijft hierin een aantal types migraine. Zo zijn er migraine aanvallen met en zonder een aura. Een dergelijk aura bestaat uit goed omschreven tijdelijke focaal neurologische functiestoornissen die meestal niet langer duren dan ongeveer 1 uur. Het betreft hier dan bijv. stoornissen van het gezichtsvermogen waaronder het zien van strepen, stippen, zigzaglijnen en zwarte vlekken, gevoelsstoornissen in een lichaamshelft, spierzwakte in een lichaamshelft en stoornissen in de taal of spraak. Meestal gaat een dergelijke aanval vooraf aan de hoofdpijnaanval.

Daarnaast zij er een groot aantal neurologische stoornissen bekend die met de migraine-aanval zelf kunnen optreden. Soms zelfs zonder gepaard te gaan met hoofdpijn.

Wat is nu de oorzaak van migraine aanvallen?

Ook hier speelt een bepaalde neurotransmitter een belangrijke rol. Het betreft hier serotonine. Het is bekend dat bepaalde bloedcellen, de bloedplaatjes, een verlaagd gehalte aan serotonine hebben in het begin van een migraine-aanval, terwijl de uitscheiding van de afbraakproducten van deze stof in de urine stijgt bij een aanval. Migraine aanvallen kunnen ook opgewekt worden door stoffen, bijv. geneesmiddelen die serotonine concentraties in het lichaam doen stijgen. Ook bepaalde voedingsmid- 
delen hebben dit effekt zoals bepaalde kaassoorten, alcoholische dranken e.a.

Serotonine speelt een belangrijke rol bij centrale serotonerge systemen, die betrokken zijn bij de regeling van de wijdte van bloedvaten in het hoofd en bij de geleiding van pijn via het zenuwstelsel. Geneesmiddelen die inwerken op de serotoninereceptoren hebben een gunstig effect op migraine hoofdpijn. Dit betreft zowel het onderdrukken van de hoofdpijnaanval zelf, alsook het voorkòmen van een dergelijke aanval. Er zijn een drietal verschillende serotoninereceptoren die elk weer verschillende subtypes kennen. Deze receptoren, die postsynaptisch gelegen zijn, bevinden zich zowel op de bloedvaten in de schedel alsook in bepaalde zenuwcentra.

Geneesmiddelen die de aanval voorkòmen zijn vnl. werkzaam op serotonine, receptoren terwijl geneesmiddelen die de aanval zelf onderdrukken inwerken op de serotonine $_{1 \mathrm{D}}$ receptor.

De exacte reden waarom mensen met migraine nu hoofdpijn krijgen is nog niet geheel duidelijk. De meest waarschijnlijke, althans recente hypothese is de veronderstelling van Moskowitz, die zowel van vasculaire als neurogene aard is. Volgens deze hypothese veroorzaakt het vrijkomen van bepaalde stoffen, neuropeptiden genaamd, een ontstekingsproces dat gepaard gaat met het uittreden van plasma uit bloedvaten en een vaatverwijding.

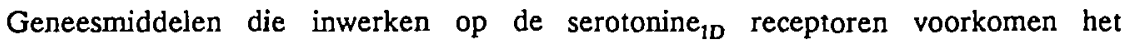
viijkomen van deze peptiden en de hiermee gepaard gaande ontstekingsreactie. Meerdere hypothesen omtrent de oorzaak van de hoofdpijn zijn echter nog actueel. De behandeling van patiënten met migraine bestaat allereerst uit het opsporen van uitlokkende factoren en het leren deze te vermijden. De meeste migraine patiënten hebben echter daarnaast nog een medicamenteuze behandeling nodig. Deze medicamenteuze behandeling kan onderverdeeld worden in 2 doelstellingen, n.l. het voorkomen van en het onderdrukken van de aanval. Middelen die de aanval onderdrukken zijn o.m. aspirine, NSAID's, ergotonine en als laatste omstreden aanwinst sumatriptan. Dit middel is niet zozeer omstreden vanwege zijn effekt op de aanval, alswel door de hoge kosten die aan het gebruik ervan verbonden zijn. Dit heeft er toe geleid dat de overheid in Nederland niet is overgegaan tot vergoeding van dit middel. Is dit een juiste beslissing?

Sumatriptan is een specifieke en selectieve agonist van serotonine ${ }_{1}$ receptoren van de 
bloedvaten in de schedel en veroorzaakt een vernauwing van deze vaten. Het middel dringt niet door in de hersenen en heeft daardoor ook geen bijwerkingen in de zin van hersenfunctiestoornissen. Het heeft ook geen invloed op het vaatstelsel buiten de hersenen zodat bloeddruk en polsfrequentie niet beïnvloed worden. Als het middel normaal via de mond wordt ingenomen, heeft het in $\pm 70 \%$ van de gevallen binnen fén uur effekt. Dit is sneller en beter dan met andere bekende medicamenten. De hoofdpijnaanval komt echter vaker binnen 48 uur terug dan bij de traditionele middelen. Deze $2 \mathrm{e}$ aanval reageert echter in het algemeen goed op nieuwe toediening van het middel. Het middel lijkt thans een belangrijk voordeel te hebben in de

behandeling van migraine. Het is effektief, veilig en werkt snel bij de aanval. Het onderdrukt alle migraineverschijnselen en niet alleen de hoofdpijn. Het werkt echter maar bij ongeveer $70 \%$ van de patiënten. De hoge kosten ( \pm f $26,--$ per tablet) remmen de toepassing op grote schaal. Het is echter de vraag of het verlies aan arbeidsproductiviteit niet leidt tot een aanmerkelijk grotere kostenpost dan het gebruik van dit middel. Aangezien dit evenwel ten laste valt van een ander departement en de onderlinge communicatie tussen departementen nog per postduif of tamtam lijkt te verlopen, zal deze vraag voorlopig wel niet worden opgelost.

\section{EPILEPSIE}

Een derde type van aandoeningen, waar ik kort de vooruitgang van wil bescbrijven, vormen de epileptische aanvallen.

Epileptische aanvallen bestaan uit plotseling gelijktijdig optredende ontladingen van grote groepen zenuwcellen in de hersenen. Dit geeft aanleiding tot voorbijgaande veranderingen van het bewustzijn of andere functiestoornissen van de hersenschors. Epileptische aanvallen kunnen het gevolg van vele verschillende ziektes zijn. Er zijn talloze aanvalstypes. Grosso modo kan gesteld worden dat er 2 aanvalstypes zijn. Ik realiseer me dat ik nu een onvergeeflijke zonde bega in de ogen van diegenen die meegewerkt hebben aan het tot standkomen van een meer verfijnde internationale classificatie van aanvalstypes, maar voor deze gelegenheid toch maar:

1e gegeneraliseerde aanvallen: dat zijn aanvallen die in beide hersenhelften gelijktijdig optreden en al dan niet gepaard gaan met spiertrekkingen 
2e partiële aanvallen: deze ontstaan in een omschreven deel van de hersenen en tonen symptomen die afhankelijk zijn van de plaats van de aanval in de hersenen. Soms gaan ze niet gepaard met een daling van het bewustzijn, en worden dan simpele partiële aanvallen genoemd, soms wel en heten dan complexe partiële aanvallen.

De diagnostiek van epileptische aanvallen is de laatste jaren sterk verbeterd door uitvoeriger neurophysiologisch onderzoek, verbeterde imaging technieken, alsmede functioneel onderzoek van de hersenen met technieken als PET-scan en SPECT-scan, waarbij gebruik gemaakt wordt van radioactieve tracers, die een oordeel toelaten over de stofwisseling en bloeddoorstroming van de hersenen.

Wat is nu de directe oorzaak voor het optreden van een epileptische aanval.

De synchrone ontlading van grote groepen zenuwcellen wordt veroorzaakt door een balansverstoring tussen exciterende en remmende processen op synaptisch niveau. Een synaps is de plaats waar twee afzonderlijke zenuwcellen via neurotransmitters elkaar beïnvloeden.

Bij mensen nu die lijden aan een secundaire epilepsie, d.w.z. een epilepsie die het gevolg is van een bepaalde oorzaak, bijv. ongeval, infectie, tumor, e.d., zijn het verlies van zenuwcellen en de hierbij optredende synaptische reorganisatie belangrijke factoren. Daarnaast is de balans tussen de exciterende neurotransmitter glutamaat en de remmende neurotransmitter GABA (gamma-aminoboterzuur) van belang.

Bij mensen die lijden aan een primaire epilepsie, d.w.z. epilepsie waarvan we de oorzaak niet kennen, kan erfelijkheid een rol spelen.

De behandeling van epilepsie is symptomatisch, d.w.z. gericht op het onderdrukken van de verschijnselen zonder de kwaal zelf te beïnvloeden. De thans meest gebruikte middelen, carbamazepine, valproaat en fenytoine zijn middelen die al meer dan 20 jaar, in het geval van fenytoine zelfs bijna 60 jaar in gebruik zijn. Recent (1991) is aan deze middelen een nieuw veelbelovend middel toegevoegd, nl. Vigabatrin, een middel dat de werking van de remmende neurotransmitter GABA versterkt. Gelukkig zijn er momenteel nog veel nieuwe middelen in een vergevorderd stadium van onderzoek. Met name bestaat er nu veel belangstelling voor middelen die de exciterende werking van bepaalde neurotransmitters tegen gaan, bijv. glutamaat. Ook 
hier betreft het dan weer middelen die hun invloed uitoefenen op de receptoren van deze stoffen, in dit geval zg. NMDA receptoren.

Afgezien van de medicamenteuze behandeling van epilepsie is de laatste jaren in Nederland ook de interesse voor de chirurgische behandeling toegenomen. Er bestaat hiertoe in Nederland een centrale werkgroep in Utrecht, die na zorgvuldige selectie en uitvoerig vooronderzoek bepaalde chirurgische behandelingsstrategieën toepast. De successen hiervan zijn zeer bemoedigend; het aantal patiënten dat per jaar voor deze vorm van behandeling in aanmerking komt is klein, mogelijk nog te klein.

Worden er nu op elk gebied in de Neurologie belangrijke therapeutische vorderingen gemaakt?

Dit kan helaas, doch dit geldt ook voor andere klinische specialismen, nog niet gesteld worden. Wel neemt de kennis omtrent de ontstaanswijze van zeer veel aandoeningen middels moderne moleculaire en genetische technieken snel toe. Toch leidt dit niet altijd direct tot therapeutische consequenties.

Eén van de aandoeningen waar de laatste jaren veel kennis over de mogelijke oorzaak is verkregen, is de ziekte van Alzheimer, de meest frequent voorkomende van alle dementiële ziektebeelden. Meerdere theorieën betreffende het ontstaan van deze aandoening hebben geleid tot pogingen tot therapie. Ook bij deze veel voorkomende, en voor de komende decennia in steeds grotere aantallen voorkomende aandoening, zijn pogingen ondernomen met toediening van neurotransmitters of chemische voorlopers hiervan. Dit vanuit hetzelfde concept als eerder genoemd bij de ziekte van Parkinson. Deze pogingen waren evenwel niet succesvol.

Zijn er nu parallellen te trekken tussen de tot dusverre beschreven ziektebeelden en de behandeling. In alle gevallen spelen moleculaire factoren een belangrijke rol. In alle gevallen was beïnvloeding van bepaalde receptoren, die door verschillende neurotransmitters gestimuleerd worden een cruciale factor.

Het meest in het oog springend is echter het feit dat nu op rationele wijze gezocht is, soms met succes, naar een middel dat een gunstig effekt op de ziektebeelden heeft. Verwacht mag dan ook worden dat in de nu afgekondigde "decade of the brain" 
belangrijke vorderingen zullen worden geboekt in de behandeling van patiënten met een neurologische aandoening.

\section{DANKWOORD}

Aan het slot van mijn betoog gekomen rest mij de aangename taak dank uit te spreken aan:

Het College van Bestuur van de Rijksuniversiteit Limburg en het Bestuur van de Faculteit der Geneeskunde van deze Universiteit, met name voor de buitengewoon snelle en vriendelijke procedure die voor mijn benoeming werd gevolgd.

De Raad van Bestuur van het Academisch Ziekenhuis Maastricht. U zag in dat voor een bloei van de Neurologie een uitbreiding in de personele sfeer nodig was. Nu deze grotendeels is ingevuld, dank zij Uw inspanningen, zijn een groot aantal problemen beter oplosbaar.

Hooggeleerde Van Nieuwenhuijzen Kruseman, als voorzitter van de benoemingscommissie hebt $U$ mij op voortvarende wijze ingevoerd in Maastrichtse organisatiestructuren.

Staf en assistenten van de vakgroep Neurologie bedank ik zeer voor de buitengewoon vriendelijke en loyale wijze waarop zij mij, als buitenstaander, in hun midden hebben geaccepteerd.

De hoogleraren Greep en Staal dank ik voor hun wijze van scouting. Ook ben ik U veel dank verschuldigd voor de wijze waarop ik voorlichting heb gekregen omtrent zuidelijke situaties en omgangsvormen.

Mevrouw van Lieshout, beste Thera, zonder jou zou ik ondanks alle voorlichting waarschijnlijk nog wat verloren rondlopen, als een kat in een vreemd pakhuis. Dank voor de uiterst plezierige wijze waarmee je mij de goede kant opstuurt. 
Tenslotte dank ik Joke voor het feit dat zij andermaal bereid was mijn centrifugale neurologische tocht door Nederland te volgen.

Ik heb gezegd en dank voor Uw aandacht. 


\section{LITERATUUR}

1. Editorial. Sumatriptan: efficacy and contribution to migraine mechanisms. J Neurol Neurosurg Psychiatry 1992;55:1103-1105.

2. C.R. Freed e.a. Survival of implanted fetal dopamine cells and neurological improvement 12 to 46 months after transplantation for Parkinsons disease. N Engl J Med 1992;327:1549-1556.

3. S. Gilman. Medical Progress. Advances in Neurology 1.

N Engl J Med 1992;326:1608-1617.

4. S. Gilman. Medical Progress. Advances in Neurology 2.

N Engl J Med 1992;326:1671-1677.

5. J.H. Growdon. Treatment for Alzheimer Disease.

N Engl J Med 1992;327:1306-1308.

6. C.D. Marsden, S. Fahn. Movement Disorders 2.

Butterworth 1987.

7. N. Shulzer, E. Mak, D.B. Calne. The antiparkison efficacy of deprenyl derives from transient improvement that is likely to be symptomatic. Ann Neurol 1992;32:795-798.

8. D.M. Silberberg. 2001 and beyond - What's ahead for Neurology? Ann Neurol 1992;32:813-817.

9. D.D. Spencer e.a. Unilateral transplantation of human fetal mesencephalic tissue into the caudate nucleus of patients with Parkinsons disease. N Engl J Med 1992;327:1541-1549. 